\title{
Myo-Inositol Monophosphatase: Diverse Effects of Lithium, Carbamazepine, and Valproate
}

Robert Vadnal, M.D., and Ranganathan Parthasarathy, Ph.D.

The therapeutic molecular sites of action for the moodstabilizing medications are unknown. Myo-inositol monophosphatase (E.C. 3.1.3.25) is a major enzyme of the inositol signaling system that has previously been shown to be inhibited by clinically relevant concentrations of lithium, implicating this enzyme as a potential therapeutic site of action in manic-depressive disorder. Inhibition of myo-inositol monophosphatase (IMPase), which converts myo-inositol monophosphates to myoinositol, results in increased levels of myo-inositol monophosphates and decreased myo-inositol available for the resynthesis of inositol phospholipids. In addition to lithium, carbamazepine and valproate are also used medically to treat manic-depressive disorder. It is of considerable interest to determine whether inhibition of
IMPase activity is a common unifying mechanism for mood-stabilizing medications. Using a partially purified myo-inositol monophosphatase preparation derived from bovine brain, we examined the effects of lithium, carbamazepine, and valproate on the IMPase reaction. These results demonstrate that (1) lithium inhibited IMPase activity in the low millimolar range, (2) carbamazepine stimulated the IMPase reaction beginning in the low-micromolar range, and (3) valproate did not demonstrate any stimulation or inhibition of IMPase. We conclude that inhibition of IMPase is not a common neurochemical mechanism for mood-stabilizing medications. [Neuropsychopharmacology 12:277-285, 1995]

tion of the enzyme myo-inositol monophosphatase (IMPase) (Berridge et al. 1982; Berridge et al. 1989; Bone et al. 1992; Drummond 1987; Nahorski et al. 1991; Parthasarathy et al. 1994; Sherman et al. 1985). The inositol cycle was discovered as a signaling system in the early 1950s (Hokin and Hokin 1955) and gradually led to the discovery of numerous calcium-mobilizing inositol-linked receptors, including serotonergic $\left(5-\mathrm{HT}_{2 \mathrm{~A}}\right)$ $\left.5-\mathrm{HT}_{2 \mathrm{~B}} / 5-\mathrm{HT}_{2} \mathrm{C}\right)$, muscarinic $\left(\mathrm{M}_{1} / \mathrm{M}_{3}\right)$, adrenergic $\left(\alpha_{1 \mathrm{~A}}\right)$ $\left.\alpha_{1 \mathrm{~B}} / \alpha_{1} / \alpha_{1 \mathrm{D}}\right)$, metabotropic (mGlu $\left.\mathrm{m}_{1}, \mathrm{mGlu}_{5}\right)$, histaminergic $\left(\mathrm{H}_{1}\right)$, cholecystokinin $\left(\mathrm{CCK}_{\mathrm{A}}, \mathrm{CCK}_{\mathrm{B}}\right)$, tachykinins $\left(\mathrm{NK}_{1}, \mathrm{NK}_{2}, \mathrm{NK}_{3}\right)$, neurotensin, bradykinin $\left(\mathrm{B}_{2}\right)$, bombesin $\left(\mathrm{BB}_{1}, \mathrm{BB}_{2}\right)$, platelet activating factor (PAF), and others (Fisher and Agranoff 1987; Watson and Girdlestone 1994). Receptor stimulation activates a family of GTP-binding proteins, $\mathrm{G}_{\mathrm{q}}$ (Hepler and Gilman 1992), which results in the hydrolysis of the inositol phospholipid, phosphatidylinositol 4, 5-bisphosphate $\left(\mathrm{PIP}_{2}\right)$, through phospholipase $\mathrm{C}$ (Rhee and Choi

\footnotetext{
From the Veterans Affairs Medical Center (RV), Psychiatry Service, Molecular Neuroscience Laboratory, Louisville, KY; Departments of Psychiatry and Biochemistry (RP), University of Louisville Medical Center, Louisville, KY.

Address correspondence to: Robert Vadnal, M.D., Veterans Affairs Medical Center, Psychiatry Service (116A), 800 Zorn Ave, Louisville, KY 40206.

Received June 28, 1994; revised October 4, 1994; accepted November 1, 1994
} 


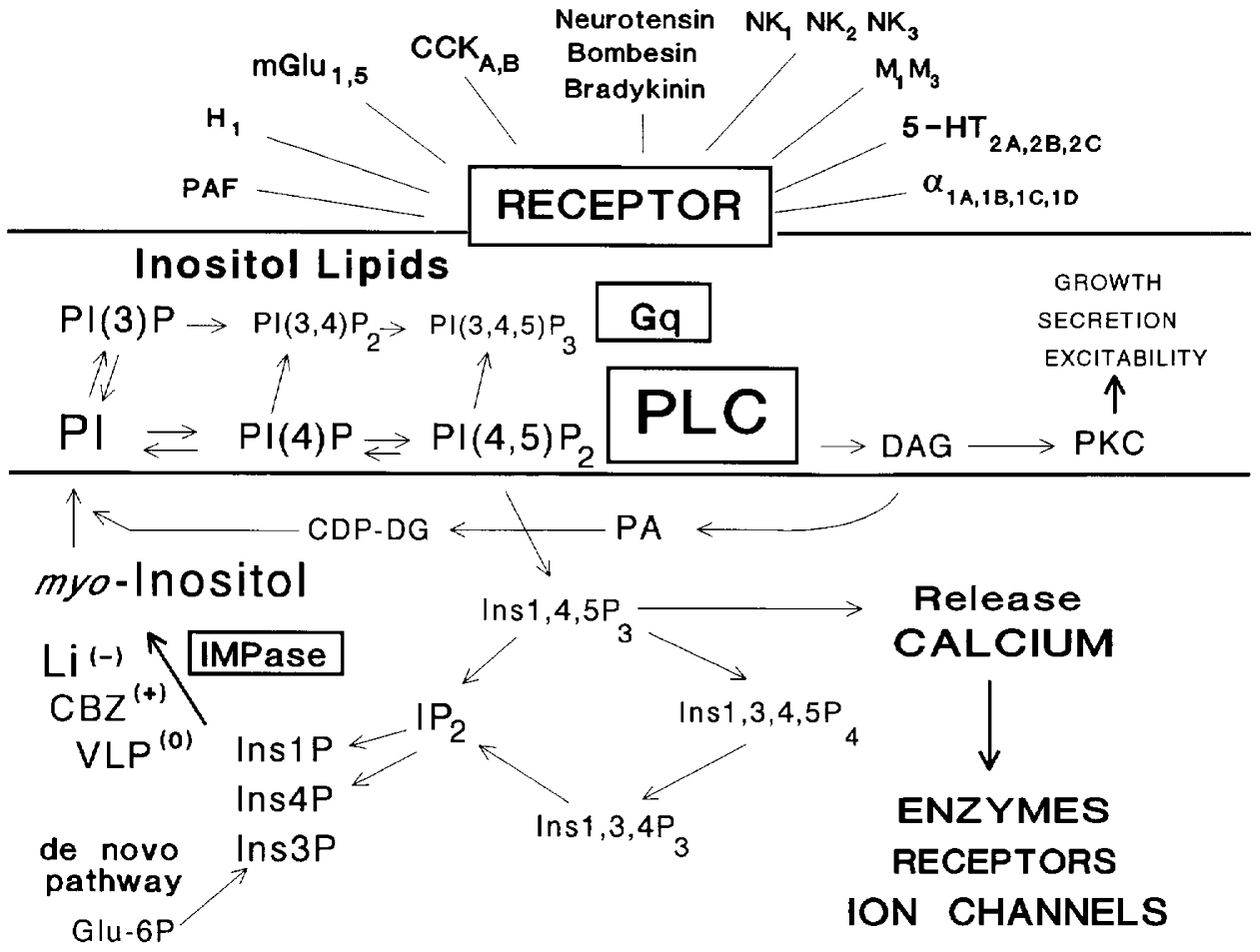

Figure 1. Overview of the inositol signaling system. Receptors linked to this signaling system include serotonergic $\left(5-\mathrm{HT}_{2 \mathrm{~A}} / 5-\mathrm{HT}_{2 \mathrm{~B}} / 5\right.$ $\left.\mathrm{HT}_{2} \mathrm{C}\right)$, muscarinic $\left(\mathrm{M}_{1} / \mathrm{M}_{3}\right)$, adrenergic $\quad\left(\alpha_{1 \mathrm{~A}} / \alpha_{1 \mathrm{~B}} / \alpha_{1 \mathrm{C}}\right)$ $\left.\alpha_{1 D}\right)$, metabotropic (MGlu, mGlus), histaminergic $\left(\mathrm{H}_{1}\right)$, cholecystokinin $\left(\mathrm{CCK}_{\mathrm{A}}\right.$, $\left.\mathrm{CCK}_{\mathrm{B}}\right)$, tachykinins $\left(\mathrm{NK}_{1}\right.$, $\mathrm{NK}_{2}, \mathrm{NK}_{3}$ ), neurotensin, bradykinin, bombesin, platelet activating factor (PAF), and others. Signal transmission requires activation of the GTP-binding protein $\left(\mathrm{G}_{\mathrm{q}}\right)$ and phospholipase C (PLC), which then hydrolyzes phosphatidylinositol 4, 5-bisphosphate $\left(\mathrm{PIP}_{2}\right)$ producing the second messengers diacylglycerol (DAG), which activates protein kinase $C(P K C)$, and myo-inositol 1, 4, 5-trisphosphate (Ins1, 4, 5 $\mathrm{P}_{3}$ ), which releases calcium from intracellular stores. The inositol polyphosphates are metabolized into the inositol monophosphates Ins1P and Ins4P, with Ins3P produced from glucose 6-phosphate (Glu-6P) via de novo synthesis. Lithium $(\mathrm{Li})$ inhibits, carbamazepine (CBZ) stimulates, and valproate (VLP) has no effect on myo-inositol monophosphatase (IMPase) activity.
1992), releasing two second messengers intracellularly: myo-inositol 1,4,5-trisphosphate $\left(\mathrm{IP}_{3}\right)$, which releases calcium from intracellular stores (Streb et al. 1983), and diacylglycerol (DAG), which is involved in the activation of protein kinase C (Nishizuka 1992). Free calcium activates a variety of enzyme, ion channels, and receptors, that amplify the initial signal into numerous signaling pathways having various physiological effects (Figure 1). The $\mathrm{IP}_{3}$ released from receptor-stimulated inositol phospholipid hydrolysis, is metabolized gradually to myo-inositol monophosphates: myo-inositol 1-phosphate (Ins1P), and myo-inositol 4-phosphate (Ins4P), which are then hydrolyzed by IMPase to free myo-inositol and phosphate. D-Myo-inositol 3-phosphate (Ins3P) (formerly L-myo-inositol 1-phosphate), is an additional inositol monophosphate derived from glucose 6-phosphate through de novo synthesis. Thus, the primary sources of myo-inositol are receptor- mediated and de novo pathways that maintain levels of myo-inositol in brain in large amounts, approximately $10 \mathrm{mM}$ (Sherman 1991). Myo-inositol then cycles into the inositol phospholipids, thus providing further substrate for receptor-linked signal transduction.

Myo-inositol monophosphatase appears to be a highly conserved enzyme phylogenetically and has been purified from rat and bovine brain, rat testicles, and lily pollen, with similar molecular weights. It exists as a homodimer with a native molecular weight of $58,000 \pm 2,000$ and individual subunit weights of $29,000 \pm 600$ as previously determined (Parthasarathy et al. 1993). A remarkable feature of this enzyme is its heat stability, demonstrating significant enzyme activity after exposure to $80^{\circ} \mathrm{C}$ for 15 minutes. IMPase is inhibited by lithium ions, and this inhibition is of the rare uncompetitive type, with a $\mathrm{K}_{\mathrm{i}}$ of $0.8 \mathrm{mM}$ (Hallcher and Sherman 1980; Nahorski et al. 1991) that is in the ther- 
apeutic range. Previously, this enzyme was considered to be cytosolic, although we identified a membranebound IMPase by Western blot analysis in brain, liver, and testicular tissue that is also inhibited by lithium with a cytosolic-to-membrane specific activity ratio of approximately 8:1 (Vadnal et al. 1992). Biochemical and stereochemical considerations led us to hypothesize a new theory for the mechanism of action of lithium on IMPase. We suggested that lithium may inhibit the formation of a myo-inositol 1,3 or 4,5-cyclic phosphate intermediate that could form from either the $D$ - or L-isomers of either Ins1P or Ins4P (Parthasarathy et al. 1992). Because lithium inhibits IMPase activity, a potential site of action in the treatment of manic-depressive disorder, it was of considerable interest to determine if the mood-stabilizing medications carbamazepine and valproate also inhibit IMPase, suggesting a common neurochemical site of action. We describe three different effects of these mood-stabilizing medications on bovine brain IMPase activity in vitro, lithium inhibition, carbamazepine stimulation, and valproate, the latter of which had no effect.

\section{METHODS}

\section{Materials}

D-myo-inositol 1-phosphate was prepared from soy bean phospholipid with some modifications as described by Ballou (1962). The carbamazepine-2-hydroxypropyl- $\beta$-cyclodextrin (HBC) complex and unconjugated $\mathrm{HBC}$ were obtained from Research Biochemical International (Natick, MA). Carbamazepine, lithium chloride, valproic acid, malachite green, ammonium molybdate, and other chemicals, were obtained from Sigma Chemical Co. (St. Louis, MO).

\section{Preparation of Bovine Brain IMPase}

A partially purified preparation of IMPase from bovine brain was prepared using a modified procedure of Parthasarathy et al. (1993). Bovine brains were obtained from a local abattoir. A four-step partial purification was performed using $536 \mathrm{~g}$ of bovine brain: (1) high-speed supernatant (10,000 rpm), (2) 40 to $60 \%$ ammonium sulfate precipitation, (3) heated at $80^{\circ} \mathrm{C}$ for $15 \mathrm{~min}$, and (4) DEAE-cellulose column. The heating step eliminated nonspecific alkaline phosphatase activity, which was tested using $p$-nitrophenyl phosphate as substrate and found to be negative. The heated enzyme preparation was dialyzed in $2 \times 4$ liters of $20 \mathrm{mM}$ of Tris- $\mathrm{HCl}$ buffer (pH 7.8) containing $1 \mathrm{mM}$ DTT and $1 \mathrm{mM}$ EGTA. The dialyzed enzyme preparation was passed on to a DEAEcellulose column $(2.5 \times 22 \mathrm{~cm})$, and a salt gradient $0-0.25 \mathrm{M}$ ) was used to elute the enzyme for the column. All the fractions were analyzed for enzyme activity. Ac- tive fractions were pooled and used as an enzyme source. This enzyme preparation demonstrated a specific activity of $421 \mathrm{mU} / \mathrm{mg}$ protein.

\section{Assay of Myo-Inositol Monophosphatase}

The IMPase assay was carried out as follows: Threetenths of a milliliter of the reaction mixture consisting of $0.05 \mathrm{ml}$ of $120 \mathrm{mM}$ Tris- $\mathrm{HCl}$ (pH 7.8), $0.05 \mathrm{ml}$ of 18 $\mathrm{mM}$ or $3 \mathrm{mM}$ magnesium chloride, $0.05 \mathrm{ml}$ of $4.2 \mathrm{mM}$ D-myo-inositol 1-phosphate, $0.125 \mathrm{ml}$ of water or different agents (lithium, carbamazepine, and valproic acid), and $0.025 \mathrm{ml}$ of enzyme was incubated at $37^{\circ} \mathrm{C}$ for 15 minutes. The enzyme assay was linear at the 15-minute time point (Eisenberg 1967). The reaction was stopped by the addition of $0.05 \mathrm{ml}$ of $20 \%$ trichloroacetic acid (TCA). The suspension was centrifuged, and $0.1 \mathrm{ml}$ of supernatant was used to estimate the liberated inorganic phosphate using malachite green reagent (Eisenberg and Parthasarathy 1987). The specific activity of the enzyme was expressed as nanomoles of phosphate liberated per minute (mU) per milligram protein. Protein was assayed using the method of Lowry et al. (1951). Each concentration of lithium, carbamazepine, and valproic acid tested was run in triplicate. Controls, run in triplicate, consisted of assay buffer, magnesium $\left(\mathrm{Mg}^{2+}\right)$, substrate, test drugs, with the enzyme added after trichloroacetic acid (TCA) addition to control for possible phosphate contamination and nonspecific substrate degradation. Controls not containing any drug were also run in triplicate. Since ordinary carbamazepine is poorly soluble in water, a special preparation of carbamazepine, carbamazepine:HBC complex, which assists in solubilization in a water-based assay, was used for most of these enzyme studies. In addition, in certain enzyme assays, natural carbamazepine was initially dissolved in ethanol $(20 \%)$ or propylene glycol $(10 \%)$ for solubilization and comparison with the carbamazepine:HBC preparation.

\section{RESULTS}

The IMPase used in these experiments was partially purified from bovine brain using a four-step procedure resulting in a specific activity of $421 \mathrm{mU} / \mathrm{mg}$ protein. Magnesium is a necessary cofactor for IMPase activity and has previously been demonstrated to stimulate the enzyme in low concentrations and to inhibit the enzyme at higher levels (Hallcher and Sherman 1980). Increasing concentrations $(0-50 \mathrm{mM})$ of $\mathrm{Mg}^{2+}$ were tested to determine the optimal concentration of this cofactor in our preparation (Figure 2). Maximal activity was observed at $3 \mathrm{mM} \mathrm{Mg}^{2+}$, which corresponds with previous reports (Gee et al. 1988; Honchar et al. 1989). Physiological levels of intracellular $\mathrm{Mg}^{2+}$ are approximately 

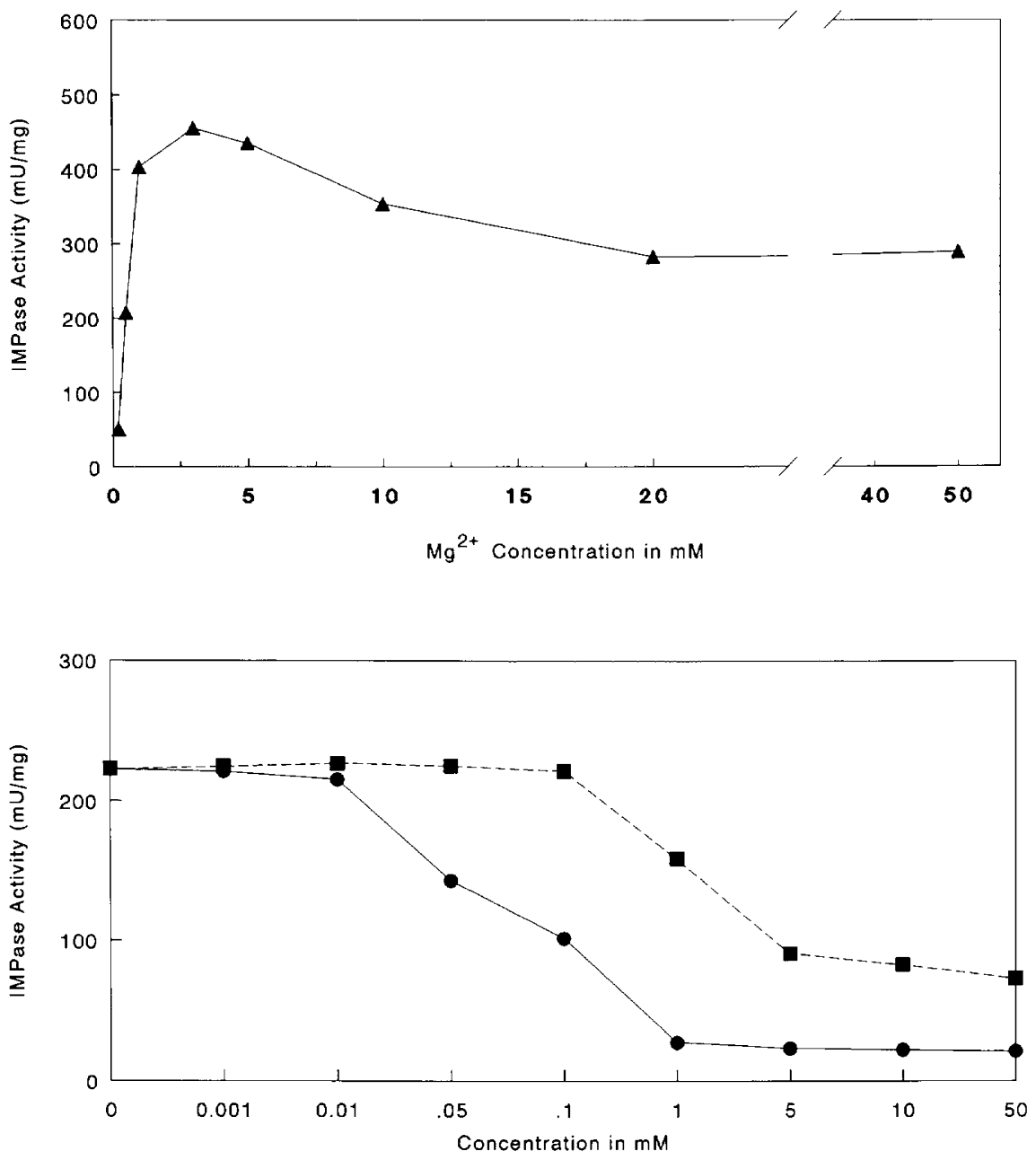

Figure 2. Effects of increasing magnesium $\left(\mathrm{Mg}^{2+}\right)$ concentrations from 0 to $50 \mathrm{mM}$ on IMPase activity. Assay conditions are noted in Methods and under Figure 4. Each point represents mean \pm $\mathrm{SD}$ of triplicate determinations; where error bar is not shown, the SD is smaller than the symbol.
Figure 3. Effects of increasing concentrations of the divalent cations calcium $\left(\mathrm{Ca}^{2+}\right)$ (filled circles) and manganese $\left(\mathrm{Mn}^{2+}\right)$ (filled squares) on IMPase activity. Assay conditions are noted in Methods and under Figure 4. Each point represents mean $\pm S D$ of triplicate determinations; where error bar is not shown, the SD is smaller than the symbol.
0.3 to $0.6 \mathrm{mM}$ (Heaton 1993). Therefore, we performed two types of in vitro IMPase assays that differed only in the concentrations of $\mathrm{Mg}^{2+}: 3 \mathrm{mM}$ (which provides maximal stimulation) and $0.5 \mathrm{mM}$ (which is a physiological concentration). The baseline activity using $3 \mathrm{mM}$ $\mathrm{Mg}^{2+}$ was approximately twice the activity obtained with $0.5 \mathrm{mM} \mathrm{Mg}^{2+}$ (Figures 2, 4).

The effects of two additional divalent cations, calcium $\left(\mathrm{Ca}^{2+}\right)$ and manganese $\left(\mathrm{Mn}^{2+}\right)$, on IMPase activity were also determined (Figure 3 ). Calcium was shown to inhibit IMPase beginning at $10 \mu \mathrm{M}$, with $\mathrm{Mn}^{2+}$ induced inhibition starting at $100 \mu \mathrm{M}$. Our results demonstrated a $63 \%$ reduction in IMPase activity with $50 \mu \mathrm{M} \mathrm{Ca}^{2+}$ and a $29 \%$ reduction with $1 \mathrm{mM} \mathrm{Mn}^{2+}$. These results are in contrast to earlier findings, which found that $\mathrm{Mn}^{2+}$ was a more potent inhibitor than $\mathrm{Ca}^{2+}$ (Hallcher and Sherman 1980). These differences are most likely due to differences in the IMPase preparation and in the assay conditions.

Lithium's therapeutic concentration ranges from 0.8 to $1.2 \mathrm{meq} / \mathrm{l}$, carbamazepine from 7 to $12 \mu \mathrm{g} / \mathrm{ml}$, and valproate from 50 to $120 \mu \mathrm{g} / \mathrm{ml}$ (Gerner and Stanton
1992). A comparison of lithium, carbamazepine (CBZ), and valproate on IMPase activity is demonstrated in Figure 4, which shows a comparison between the $3 \mathrm{mM}$ $\mathrm{Mg}^{2+}$ and $0.5 \mathrm{mM} \mathrm{Mg}^{2+}$ IMPase assay. Lithium exhibited a similar pattern of inhibition under both assay conditions (Figure 4), with increasing inhibition from 0.1 to $10 \mathrm{mM} \mathrm{LiCl}$. At $1 \mathrm{mM}$, IMPase activity was inhibited by $17 \%$ ( $3 \mathrm{mM} \mathrm{Mg}^{2+}$ assay) and $16 \%(0.5 \mathrm{mM}$ $\mathrm{Mg}^{2+}$ assay). Valproate was tested for effects on IMPase activity with concentrations from $2 \mu \mathrm{M}$ to $5 \mathrm{mM}$, demonstrating no effects on enzyme activity. In contrast to the inhibitory effect of lithium and to the lack of effect of valproate, carbamazepine $\left(0.5 \mathrm{mM} \mathrm{Mg}{ }^{2+}\right.$ IMPase assay) demonstrated a $32 \%$ stimulation of IMPase that began at $1 \mu \mathrm{M}$ and gradually increased throughout the concentrations tested to a $74 \%$ increase in activity at $1 \mathrm{mM}$ (Figure 4). Stimulation was also noted in the $3 \mathrm{mM} \mathrm{Mg}^{2+}$ IMPase assay. However, the overall stimulation pattern was less pronounced with a maximal stimulation of $18 \%$ at $1 \mathrm{mM}$. The carbamazepine preparation used in these experiments was the carbamazepine:HBC complex (see Materials). HBC alone 
Figure 4. Effects of lithium (filled squares), valproate (filled circles), and carbamazepine (filled triangles) on IMPase activity. Each point represents mean \pm SD of triplicate determinations; where error bar is not shown, the SD is smaller than the symbol; ${ }^{\star \star} p<.01$ comparing drug-treated with control assays using Student's twotailed $t$ test. $25 \mu \mathrm{l}$ of partially purified IMPase in a total volume of $300 \mu \mathrm{l}$ was incubated at $37^{\circ} \mathrm{C}$ for 15 minutes at $\mathrm{pH}$ 7.8 as detailed in Methods. The specific activity of the enzyme was expressed as nanomoles of phosphate liberated per minute $(\mathrm{mU})$ per milligram protein. The initial values shown on the $y$-axis are baseline values of IMPase activity for each drug tested. Lithium inhibited, carbamazepine stimulated, and valproate did not effect IMPase activity. (A) IMPase assay with $3 \mathrm{mM}$ $\mathrm{Mg}^{2+}$ to provide maximal $\mathrm{Mg}^{2+}$-induced IMPase stimulation, (B) IMP assay with $0.5 \mathrm{mM} \mathrm{Mg}^{2+}$, which is a physiological concentration of $\mathrm{Mg}^{2+}$.

Figure 5. Effects of three different preparations of carbamazepine on IMPase activity. Carbamazepine was increased from 0 to $1 \mathrm{mM}$, and the IMPase assay was done as noted in Methods and Figure 4. Each point represents mean \pm SD of triplicate determinations; where error bar is not shown, the SD is smaller than the symbol; ${ }^{* *} p<.01$ comparing drugtreated with control assays using Student's two-tailed $t$ test. Three different carbamazepine preparations were compared for effects on IMPase activity: carbamazepine in $3.66 \%$ ethanol (solid triangles), $1.33 \%$ propylene glycol (solid circles), and carbamazepine:HBC complex (solid diamonds). All three preparations demonstrated carbamazepine-induced stimulation of IMPase.
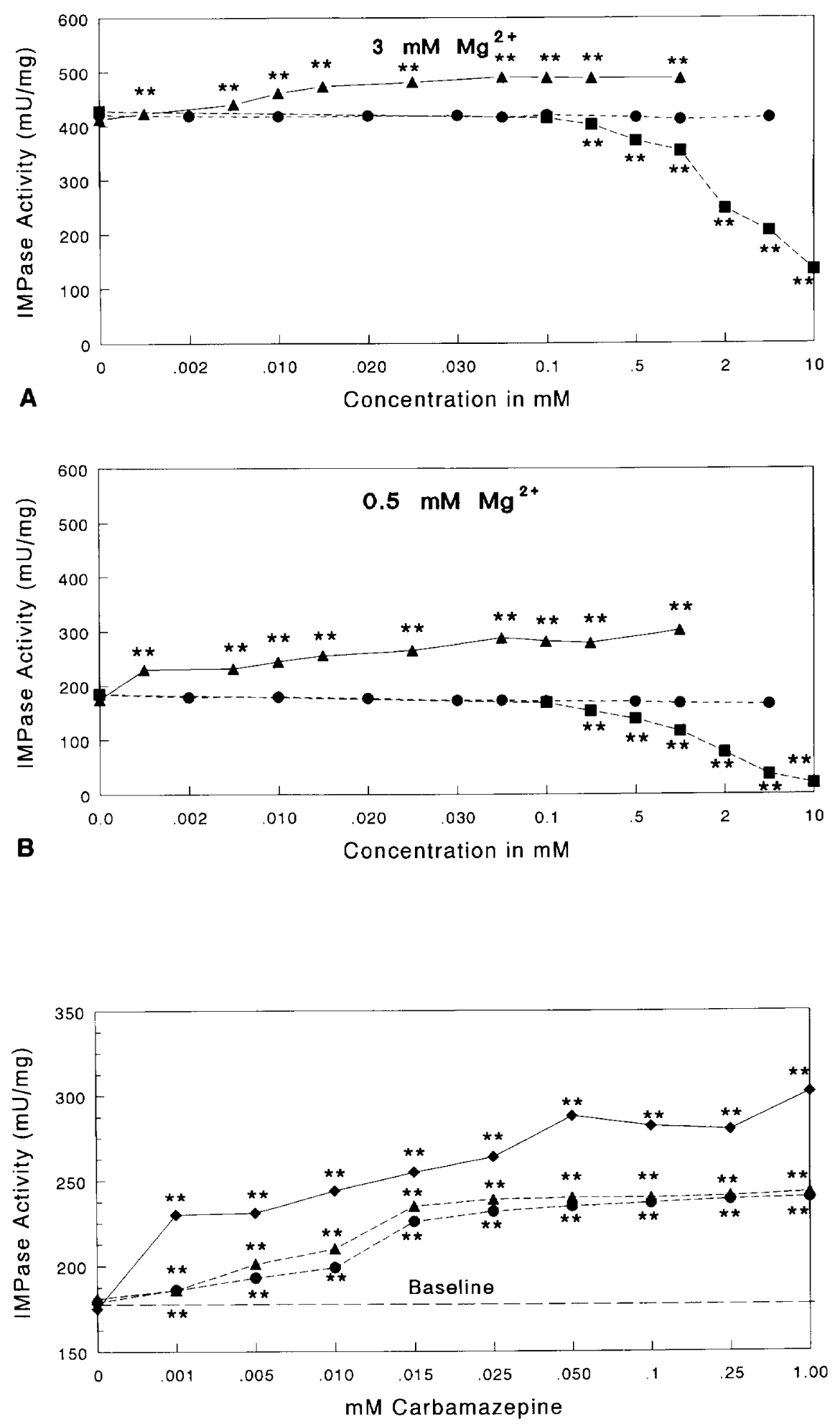

demonstrated no effect on IMPase activity at any concentration $(1 \mu \mathrm{M}-2 \mathrm{mM})$.

To further confirm the stimulatory effect of carbamazepine noted with the carbamazepine:HBC prep- aration, IMPase activity was determined using carbamazepine dissolved in ethanol $(20 \%)$ and also in propylene glycol $(10 \%)$ with final concentrations of $3.33 \%$ and $1.66 \%$, respectively (Figure 5). At these con- 
centrations no stimulatory or inhibitory effects of ethanol or propylene glycol were noted on IMPase activity. In comparing three different carbamazepine preparations - carbamazepine in $\mathrm{HBC}$, ethanol, and propylene glycol - all three formulations demonstrated a stimulation of IMPase activity, with carbamazepine:HBC demonstrating the largest increase. These effects of IMPase activity by lithium, carbamazepine, and valproate were noted in both the $0.5 \mathrm{mM} \mathrm{Mg}^{2+}$ and the $3 \mathrm{mM} \mathrm{Mg}^{2+}$ IMPase assays, with the largest increases occurring in the $0.5 \mathrm{mM} \mathrm{Mg}{ }^{2+}$ enzyme assays, suggesting that these effects may occur physiologically. The low micromolar effects of carbamazepine and the low millimolar effects of lithium are in clinically relevant concentrations for each.

\section{DISCUSSION}

Lithium and the inositol system have been linked since Allison and Stewart (1971) first demonstrated that acute administration of lithium resulted in a 30\% decrease in inositol levels in rat cerebral cortex. It was subsequently determined that the decrease in inositol was caused by inhibition of the enzyme IMPase, which converts myoinositol monophosphates to myo-inositol (Hallcher and Sherman 1980) that is then reincorporated into inositol phospholipids. The inositol depletion hypothesis is a strong candidate for the mechanism of action of lithium and may be the therapeutic site of action in the treatment of manic-depressive disorder and has led to the further study of IMPase in order to design future moodstabilizing drugs (Berridge et al. 1982; Belmaker and Kofman 1990; Bone et al. 1992; Drummond 1987; Kofman and Belmaker 1993; Nahorski et al. 1991; Sherman et al. 1985). The control of intracellular levels of myoinositol depends primarily on the action of IMPase that hydrolyzes myo-inositol monophosphates derived from (1) cell stimulation producing Ins1P, Ins4P, and (2) de novo synthesis from glucose forming Ins3P. Myoinositol is available for reincorporation into the inositol lipid pool, thereby affecting signal transduction through the inositol signaling system. In addition to lithium, carbamazepine and valproate are also commonly being used in the treatment of manic-depressive disorder (German and Stanton 1992). Therefore it is of considerable interest to determine whether each of these mood-stabilizing medications has a similar inhibitory effect on IMPase.

The major finding in this study is that all three drugs had different effects on IMPase. At clinically relevant levels IMPase activity was shown to be inhibited by lithium (low millimolar) and stimulated by carbamazepine (low micromolar), with no effect demonstrated by valproate. At first glance, the fact that these three moodstabilizing medications have different effects on the
IMPase reaction may suggest to some that the inositol system may not be a therapeutic site of action for moodstabilizing medications. However, this does not consider the possibility that these medications may act at different or multiple sites within the inositol signaling system or that selective neurotransmitter systems may be involved. Interruption of the inositol cycle within specific neurotransmitter systems at the level of myoinositol monophosphatase would lead to decreased levels of intracellular inositol. This would result in decreased signal transmission within a particular neuronal system that might be excitatory or inhibitory on other circuits involved in the syndrome of either manic or depressive states. Berridge et al. (1982) originally proposed that lithium would be most effective in hyperactive cells as opposed to quiescent cells (i.e., cells or neuronal circuits that are highly stimulated will experience inositol depletion and decreased production of inositol lipids reducing signal transmission). Studies regarding myo-inositol monophosphatase have demonstrated that lithium inhibited this enzyme (Hallcher and Sherman 1980; Naccarato et al. 1974) and did so at clinically relevant concentrations of approximately $1 \mathrm{mM}$ (Hallcher and Sherman 1980). Our present study demonstrated a similar lithium inhibition profile on IMPase activity, using both the $3 \mathrm{mM} \mathrm{Mg}^{2+}$ (maximal stimulation) and $0.5 \mathrm{mM} \mathrm{Mg}^{2+}$ (physiological $\mathrm{Mg}^{2+}$ ) enzyme assays (Figure 4). Chronic lithium studies in rat brain have been shown to increase (Renshaw et al. 1986) or have no effect (Honchar et al. 1989) on IMPase activity. Further studies are required to clarify these findings.

Behaviorally, lithium has been shown to inhibit rearing in rats (Kofman and Belmaker 1993), and this behavioral effect was reversed with both myo- and L-chiro-inositol. In addition, myo-inositol has been shown to inhibit lithium-pilocarpine limbic seizures in mice (Tricklebank et al. 1991) and in rats (Kofman et al. 1991). In the latter study, myo-inositol was compared to L-chiro-inositol and was found to specifically decrease seizure activity, with decreases noted in both seizure latency and severity. These seizures occur in lithium pretreated rats who receive subconvulsant doses of pilocarpine, resulting in limbic seizures (Honchar et al. 1989). These studies raise the issue of potential anticonvulsant effects of increased myo-inositol levels. This lithium-pilocarpine induced limbic seizure model has been suggested to be a behavioral model that would identify new lithiumlike drugs (Kofman and Belmaker 1993).

In human studies Agam and Livne (1989) first demonstrated that IMPase could be measured in human erythrocytes, demonstrating the feasibility of measuring IMPase in a psychiatric patient population. Moscovich et al. (1990) studies IMPase in three groups of bipolar (manic-depressive) patients (1) not treated 
with lithium, (2) treated with lithium, and (3) normal controls. The untreated bipolar patients showed IMPase activity similar to control patients. Bipolar patients treated with lithium demonstrated an approximate $80 \%$ inhibition of red blood cell IMPase activity. Further studies of this type will determine if IMPase activity correlated with various subgroups of bipolar disorder patients or have predictive value with regard to medication selection or clinical course.

Depressed patients were noted to have decreased levels of inositol in the cerebrospinal fluid (CSF) (Barkai et al. 1978). Using an open design, Levine et al. (1993) treated patients diagnosed as having treatmentresistant depression with large doses of inositol $(6 \mathrm{~g}$ per day) for 4 weeks and demonstrated an impressive reduction in depressive symptoms in 9 out of 11 patients. It should be noted that these patients did not have bipolar disorder, depressive phase, but rather met the DSM-III-R criteria for major depressive disorder, which excludes bipolar patients. Studies have not yet been done on bipolar patients in the depressed phase with inositol supplementation, which may prove to be of therapeutic benefit.

The effectiveness of carbamazepine and valproate in the treatment of manic-depressive disorder has been established although the underlying molecular mechanisms of action are unknown (McElroy et al. 1992; Post et al. 1991, 1992). Patients who are lithium-resistant may respond to carbamazepine or valproate, suggesting that this disorder is heterogeneous with regard to both clinical features and medication response. Do these alternative mood-stabilizing medications modulate the inositol signal system similar to lithium? Valproate was shown in this study to have no effect on IMPase activity in vitro from micromolar to millimolar concentrations (Figure 4). Li et al (1993), using a brain slice model, demonstrated a regional inhibitory effect of valproate on inositol signaling in rat striatum but not frontal cortex in rats treated for 28 days. Few studies have explored the effects of valproate on the inositol system, and more basic and clinical studies are needed. However, valproate and lithium do not share IMPase inhibition as a common site of action.

In contrast, we have demonstrated that carbamazepine stimulates IMPase activity in vitro, beginning at low micromolar concentrations that are clinically relevant (Figure 4). This stimulatory effect should increase intracellular levels of free myo-inositol, an effect directly opposite to that of lithium. However, an increase in myo-inositol levels does not necessarily result in an increase in inositol phospholipids. It is possible that other metabolic and signaling pathways may be modulated. Since it has been demonstrated that giving myo-inositol intraventricularly in rats attenuates lithium-pilocarpine limbic seizures (Kofman and Belmaker 1993), further studies need to be done to explore the novel possibility that increasing myo-inositol levels may have anticonvulsant effects in certain types of seizures. A major question is whether carbamazepine stimulates IMPase in vivo. Using an acute in vivo model with rats pretreated with carbamazepine, we previously demonstrated a decrease in basal levels of inositol monophosphates $\left(\mathrm{IP}_{1}\right)$ in rat cerebral cortex $(15 \%)$ and hippocampus $(17 \%)$, which suggested an increase in IMPase activity in vivo (Vadnal and Bazan 1988). The decreased levels of $\mathrm{IP}_{1}$ in carbamazepine-treated rats, contrasted with lithium-pretreatment that demonstrated elevated basal levels of $\mathrm{IP}_{1}$ using an in vivo preparation (Vadnal and Bazan 1987). Further in vivo studies are needed to clarify this area.

Drug development in the area of mood-stabilizing medications is based on IMPase inhibition. Several IMPase inhibitors have been developed as lithium like medications such as K-76 monocarboxylic agents (Pachter 1991), a sesquiterpene derivative L-671,776 (Lam et al. 1992), methylenebis-phosphonic acid (Kulagowski et al. 1991), and D- and L- myo-inositol 1-phosphothiorates (Baker et al. 1991). As the molecular mechanisms of action for lithium carbamazepine and valproate are further understood, new sites of action in the signal transduction pathway will be targeted in addition to IMPase inhibition.

\section{ACKNOWLEDGMENTS}

Supported by VA Medical Research Funds (REV) and in part by Abbott Laboratories.

\section{REFERENCES}

Agam G, Livne A (1989): Inositol 1-phosphatase of human erythrocytes is inhibited by therapeutic lithium concentrations. Psychiatry Res 27:217-224

Allison JH, Stewart MA (1971): Reduced brain inositol in lithium treated rats. Nature New Biol (Lond) 233:267-268

Baker GR, Billington DC, Gani D (1991): Synthesis of D- and L-myo-inositol 1-phosphorothioate, substrates for inositol monophosphatase. Tetrahedron 47:3895-3908

Ballou CE (1962): Myo-inositol 1-phosphate. Biochem Prep 9:99-102

Barkai IA, Dunner DL, Gross HS, Mayo P, Fieve RR (1978): Reduced myo-inositol levels in cerebrospinal fluid from patients with affective disorder. Biol Psychiatry 13:65-72

Belmaker RH, Kofman O (1990): Lithium research: State of the art. Biol Psychiatry 27:1279-1281

Berridge MJ, Downes CP, Hanley MR (1982): Lithium amplifies agonist-dependent phosphatidylinositol responses in brain and salivary glands. Biochem J 206:587-595 
Berridge MJ, Irvine RF (1989): Inositol phosphates and cell signalling. Nature 341:197-205

Bone R, Springer JP, Atack JR (1992): Structure of inositol monophosphatase, the putative target of lithium therapy. Proc Natl Acad Sci USA 89:10031-10035

Drummond AH (1987): Lithium and inositol lipid-linked signaling mechanisms. Trends Pharmacol Sci 8:129-133

Eisenberg F Jr (1967): D-Myoinositol 1-phosphate as product of cyclization of glucose 6-phosphate and substrate for a specific phosphatase in rat testis. J Biol Chem 242: $1375-1382$

Eisenberg F Jr, Parthasarathy R (1987): Measurement of biosynthesis of myo-inositol from glucose 6-phosphate. Meth Enzymol 141:127-143

Fisher SK, Agranoff BW (1987): Receptor activation and inositol hydrolysis in neural tissues. J Neurochem 48:9991017

Gee NS, Ragan CI, Watling KJ, Aspley S, Jackson RG, Reid GG, Gani D, Shute JK (1988): The purification and properties of myo-inositol monophosphatase from bovine brain. Biochem J 249:883-889

Gerner RH, Stanton A (1992): Algorithm for patient management of acute manic states: Lithium, valproate, or carbabazepine? J Clin Psychopharmacol 12:57S-63S

Hallcher LM, Sherman WR (1980): The effects of the lithium ion and other agents on the activity of myo-inositol-1phosphatase from bovine brain. J Biol Chem 255:1089610901

Heaton FW (1993): Distribution and function of magnesium within the cell. In Birch NJ (ed), Magnesium and the Cell, London, Academic Press, pp 121-136

Hepler JR, Gilman AG (1992): G proteins. Trends Biochem Sci 17:383-387

Hokin LE, Hokin MR (1955): Effects of acetylcholine on the turnover of phosphoryl units in individual phospholipids of pancreas slices and brain cortex slices. Biochim Biophys Acta 18:102-110

Honchar MP, Ackerman KE, Sherman WR (1989): Chronically administered lithium alters neither myo-inositol monophosphatase activity nor phosphoinositide levels in rat brain. J Neurochem 53:590-594

Kofman O, Belmaker RH (1993): Biochemical, behavioral, and clinical studies of the role of inositol in lithium treatment and depression. Biol Psychiatry 34:839-852

Kofman O, Belmaker RH, Grisaru N, Alpert C, Fuchs I, Katz V, Rigler O (1991): myo-inositol attenuates two specific behavioral effects of acute lithium in rats. Psychopharmacol Bull 27:185-190

Kulagowski JJ, Baker R, Fletcher SR (1991): Inhibitors of myoinositol monophosphatase containing methylenebisphosphonic acid as a replacement for a phosphate group. J Chem Soc Chem Commun 1649-1650

Lam YKT, Wichmann CF, Meinz MS, Guariglia L, Giacobbe RA, Mochales S, Kong L, Honeycutt SS, Zink D, Bills GF, Huang L, Burg RW, Monaghan RL, Jackson R, Reid G, Maguire JJ, McKnight AT, Ragan CI (1992): A novel inositol monophosphatase inhibitor from Memnoniella echinata. J Antibiot 45:1397-1403

Levine J, Gonzalves M, Barbur I, et al. (1993): Inositol $6 \mathrm{gm}$ daily may be effective in depression but not schizophrenia. Hum Psychopharmacol 8:49-53
Li R, Wing LL, Wyatt RJ, Kirch DG (1993): Effects of haloperidol, lithium and valproate on phosphoinositide turnover in rat brain. Pharmacol Biochem Behav 46: 323-329

Lowry OH, Rosebrough NJ, Farr AL, Randall RJ (1951): Protein measurement with the Folin-phenol reagent. J Biol Chem 193:265-275

McElroy SL, Keck PE Jr, Pope HG Jr, Hudson JI (1992): Valproate in the treatment of bipolar disorder: Literature review and clinical guidelines. J Clin Psychopharmacol $12: 42 S-52 S$

Moscovich D, Belmaker RH, Agam G, Livne A (1990): Inositol 1-phosphatase in red blood cells of manic-depressive patients before and during treatment with lithium. Biol Psychiatry 27:552-555

Naccarato WF, Ray RE, Wells WW (1974): Biosynthesis of myo-inositol in rat mammary gland. Isolation and properties of the enzymes. Arch Biochem Biophys 164:194- 201

Nahorski SR, Ragan CI, Challis RAJ (1991): Lithium and the phosphoinositide cycle: An example of uncompetitive inhibition and its pharmacological consequences. Trends Pharmacol Sci 12:297-303

Nishizuka Y (1992): Intracellular signalling by hydrolysis of phospholipids and activation of protein kinase C. Science 258:607-614

Pachter JA (1991): Noncompetitive inhibition of inositol monophosphatase by K-76 monocarboxylic acid. Mol Pharmacol 40:107-111

Parthasarathy R, Parthasarathy L, Ramesh TG, Shyamaladevi CS, Vadnal RE (1992): The effects of lithium isotopes on the myo-inositol 1-phosphatase reaction in rat brain, liver, and testes. Life Sci 50:1445-1450

Parthasarathy L, Vadnal RE, Ramesh TG, Shyamaladevi CS, Parthasarathy R (1993): Myo-inositol monophosphatase from rat testes: Purification and properties. Arch Biochem Biophys 304:94-101

Parthasarathy L, Vadnal RE, Parthasarathy R, Shyamaladevi CS (1994): Biochemical and molecular properties of lithium-sensitive myo-inositol monophosphatase. Life Sci 54:1127-1142

Post RM, Altshuler LL, Ketter TA, Denicoff K, Weiss SR (1991): Antiepileptic drugs in affective illness: Clinical and theoretical implications. Adv Neurol 55:239-277

Post RM, Weiss S, Chuang D (1992): Mechanisms of action of anticonvulsants in affective disorders: Comparisons with lithium. J Clin Psychopharmacol 12:23S-35S

Renshaw PF, Joseph NE, Leigh JS (1986): Chronic dietary lithium induces increased levels of myo-inositol 1-phosphatase activity in rat cerebral cortex homogenates. Brain Res 380:401-404

Rhee SG, Choi KD (1992): Regulation of inositol phospholipidspecific phospholipase $C$ isozymes. J Biol Chem 267: 12393-12396

Sherman WR (1991): Lithium and the phosphoinositide signaling system. In Birch NJ (ed), Lithium and the Cell, London, Academic Press, pp 121-157

Sherman WR, Munsell LY, Gish BG, Honchar MP (1985): Effects of systemically administered lithium on phosphoinositide metabolism in rat brain, kidney, and testis. J Neurochem 44:798-807 
Streb H, Irvine RF, Berridge MJ, Schultz I (1983): Release of calcium from a non-mitochondrial intracellular store in pancreatic acinar cells by inositol-1,4,5-trisphosphate. Nature 306:67-69

Tricklebank MD, Singh L, Oles RJ (1991): Evidence that a proconvulsant action of lithium is medicated by inhibition of myo-inositol phosphatase in mouse brain. Brain Res 558:145-148

Vadnal RE, Bazan NG (1987): Electroconvulsive shock stimulates polyphosphoinositide degradation and inositol trisphosphate accumulation in rat cerebrum: Lithium pretreatment does not potentiate these changes. Neurosci Lett 80:75-79
Vadnal RE, Bazan NG (1988): Carbamazepine inhibits electroconvulsive shock-induced inositol trisphosphate $\left(\mathrm{IP}_{3}\right)$ accumulation in rat cerebral cortex and hippocampus. Biochem Biophys Res Commun 153:128-134

Vadnal RE, Parthasarathy R, Parthasarathy L, Ramesh TG, Shyamaladevi CS (1992): The identification of a membrane-bound myo-inositol 1-phosphatase in rat brain, liver, and testes. Biochem Int 26:935-941

Watson S, Girdlestone D (1994): Receptor and ion channel nomenclature supplement. Trends Pharmacol Sci 15:1-51 